Volume 6 Issue 4, December 2019

Nationally Accredited Journal,

Decree No. B/4130/E5/E5.2.1/2019

\title{
Notary Role In The Bonding Object To The Settlement Of Liability Rights In Banking Credit Loss (Case Study In Semarang)
}

\author{
Arya Fathurahman ${ }^{1}$, Sulistyo Utomo ${ }^{2}$, Amin Purnawan ${ }^{3}$ and \\ Setyawati ${ }^{4}$
}

Abstract. The purpose of this study was to: 1) To Assess and analyze the role of the Notary in binding Collateral Object Encumbrance against Settlement Bad Debt in the city, 2) to Review and Analyze Effects, Barriers and Solutions in fastening places Encumbrance if not done before Notary, The method used in this study using a normative legal research legal research conducted by reviewing the materials are derived from legislation and other materials from a variety of literature.

Based on the results of data analysis concluded that: 1) the importance of the role of the Notary that leads to Article 15 (1) UUHT determine that importance a strand Attorney Imposing Mortgage (SKMHT) shall be made by notarial deed or deed of PPAT. 2) The legal consequences for binding Binding Objects Encumbrance if not done in the presence of a Notary (1) agreements that do lose their authenticity as stated in Article 16 paragraph (8) UUJN, (2) the lender does not get a position that takes precedence (droit de preference), (3) in the event of default, the guarantee can not be directly executed, (4) proof of the deed made does not apply to third parties, so that the settlement be reached only through a settlement amicably, (5) affects the motivation of members financing to meet with a good performance. As for barriers and solutions if agreement encumbrance not done before Notary can be divided into three, namely: (1) prior to binding, associated with the filing requirements of the binding as of the identity of the parties, the object of the guarantee, and is authorized to act by the parties, (2) binding collateral, related to the change in attitude of the debtor and the binding process at the local BPN (3) after the binding, associated with the increase of SKMHT be APHT and roya against collateral.

Keywords: Role of the Notary; Binding Objects Mortgage; Bad Debt.

\section{Introduction}

Notary whose expertise in the field of law can provide assistance with the advice given by it to the Community which require, as well as with the preparation of the Authentic Deeds, in order to achieve what required by the people who need the services of a Notary Public. In preparation of the Deed that is located Skills and Art of a Notary Public. In the application of the Law, so as to meet the intent and desire of the parties makes agreement, leaving no law that applies even so may cause the Case New Law (neubulding) and seek settlement where the law / Act does not set out clear regarding a case / cases.

The function of notaries who can make Authentic Deed which is a tool that has the fullest strongest proof and in every relation Important Role of Law in public life. In various Legal Relations in Business Sector, Banking, even in Social Work, Need for

\footnotetext{
${ }^{1}$ Students of Master of Notary Law, Faculty of Law, Universitas Islam Sultan Agung Semarang, employment of PT. Bank Mandiri (Persero) Tbk. E-mail:arya.mcreary@yahoo.co.id

${ }^{2}$ Students of Master of Law, Faculty of Law, Universitas Islam Sultan Agung Semarang, email listy0610@gmail.com

${ }^{3}$ Lecturer of Faculty of Law, Sultan Agung Islamic University Semarang

${ }^{4}$ Lecturer of Faculty of Law, Sultan Agung Islamic University Semarang
} 
Evidence Written in the form of increasingly Ascending Authentic deed along with the development of demand for Rule of Law in a range of Economic and Social Activities, both at National and International Level. ${ }^{5}$

With the deed Authentic provide Legal Certainty for holders to avoid disputes in the future. Although in case the dispute can not be avoided, this is an Authentic Deed Written Evidence has proof that the Perfect Power of the Uniform Dispute Resolution Process. ${ }^{6}$

In this case along with the development Notary great influence especially within each Operational Transaction Banking, particularly in the manufacture of Deed of Credit Agreement / financing as well as the creation of the Acts related to the completion of the Credit Agreement.

Under Article 1, paragraph (11) of Law No. 10 of 1998 on the Amendment of Law Number 7 of 1992 concerning Banking, stated definition of credit is "Provision of money or deal Borrowing between the Bank and other Persons Requiring Borrower to repay the debts after Specific time period to Giving Flowers ".

Credit agreements according to the Civil Code is included in the Loan Agreement and borrowing set forth in Civil Code Section 1754-1769. Pursuant to Article 1754 of the Civil Code states that: Borrowing is an agreement by which the parties One Delivers the other Party a certain amount of goods that annihilate because of a requirement, the requirement that the latter will return a similar amount of sorts and conditions same. $^{7}$

Based on these descriptions, were interested to examine it in by doing research, to writing thesis entitled "The role of the Notary in places Binding Settlement Against Mortgage Bad Debt in Banking (Case Study In Semarang)".

The formulation of the problem to be investigated in this study is about the role of the Notary in the binding of the object of mortgage collateral against the loan resolution in Semarang and legal consequences, obstacles and solutions in the object binding encumbrance if not performed before a Notary.

\section{Research methods}

Empirical juridical approach. Juridical (the law is seen as the norm or das sollen), because in this study to address issues using legal materials. Empirical approach (law as a social reality, cultural or das sein), because in this study used primary data obtained from the field. ${ }^{8}$

This type of research is used in completing this thesis is qualitative research, the research can be defined as research that is not as concerning ${ }^{9}$ And described in the analysis and discussion.

The data used are primary and secondary data. To obtain primary data researchers refer to data or facts and case obtained directly through fieldwork included a

\footnotetext{
${ }^{5}$ GHS Lumban Tobing, 1996, Peraturan Jabatan Notaris, Erlangga, Jakarta, p. 90

6 Indrawati Soewarso, 2002, Jaminan-jamian Untuk Pemberian Kredit Menurut Hukum Indonesia, Indonesian Bankers Institute, Jakarta, p 31

${ }^{7}$ Subekti and Tjitrosudibio, 1995, Terjemahan Kitab Undang-Undang Hukum Perdata (Burgerlijk Wetboek), Ed. XIX. Prad Paramita, Jakarta, p. 176

${ }^{8}$ Soerjono Soekanto \& Sri Mamudji, 2001, Penelitian Hukum Normatif (Suatu Tinjauan Singkat), Rajawali Pers, Jakarta, p. 13-14

9 Ediwarman, 2010, Monograf, Metodologi Penelitian Hukum, Medan: Graduate Univ. Muhammadiyah North Sumatra, Medan, p. 24
} 
Volume 6 Issue 4, December 2019

Nationally Accredited Journal,

Decree No. B/4130/E5/E5.2.1/2019

description of the respondents. While the secondary data is done by means of a literature study.

Legal materials used in this study were obtained from search through the study of literature, namely the collection of data obtained from sources of literature, scientific papers, legislation and other written sources relating to the matter being investigated as a theoretical basis.

Data analysis method used is descriptive qualitative, the decomposition of data analysis that starts on information obtained from the respondents to achieve clarity issues to be discussed. ${ }^{10}$

\section{Results and Discussion}

\subsection{Notary role in the binding of collateral object to the Settlement Loans Mortgage Loss in Semarang}

The role of the notary is not always dominant eraser legal acts, salash only the credit agreement. When the credit agreement generally has been made in accordance with the will of the creditors. But for the value of lending or loans above Rp. 20.000.000, (Twenty Million) installment loan agreement obliges banks fiduciary system was created directly by notaries who are authentic deed. As for the fiduciary system installment credit agreements with credit scores below Rp. 20.000.000, - (Twenty Million), notary simply knowing or installment credit agreement to legalize the fiduciary system. ${ }^{11}$

As for the bonding / object of the fiduciary nature of loading additional agreements / follow-on installment credit agreements fiduciary systems, the role of the Notary is necessary to perform registration to the registration of fiduciary in the Office of the Department of Law and Human Rights locals. This is done in order to obtain banking or rights of preferred position of the object other top the fiduciary insurance.

Furthermore, in practice the important role of the Notary in the financing agreement and binding of collateral, notary deed make that is authentic because it is the authority of Notary dai. ${ }^{12}$ It led to Article 15 (1) UUHT which determines that the Power of Attorney Imposing Mortgage (SKMHT) shall be made by notarial deed or deed of PPAT. In this case the Notary a deed for their requests from the parties to Notary will not make the deed any, and the Notary will not make the deed any, and Notary a deed is based on evidence or information or statements attentio / parties stated or explained or disclosed to or before the Notary, and then Notary frame outward, formal and material in the form of notarial deed, to remain grounded in the rule of law and procedure or procedures deed and rules of law relating to legal actions in question are set forth in the deed. ${ }^{13}$

\footnotetext{
${ }^{10}$ Afifuddin, et al, 2009, Metodologi Penelitian Kualitatif, Pustaka Setia, Bandung, p. 15

${ }^{11}$ Sjaifurrachman, 2011, Aspek Pertanggungjawaban Notaris Dalam Pembuatan Akta, Mandar Maju, Bandung, p. 67

12 Taudikhul Afkar, 2017, "Analisis Pengaruh Kredit Macet dan Kecukupan Likuiditas Terhadap Efisiensi Biaya Operasional Bank Umum Syariah di Indonesia", Asian Journal of Innovation and Entrepreneurship Vol. 2 No. 2.

${ }^{13}$ Habib Adjie 2008, Hukum Notaris Indonesia-Tafsir Tematik Terhadap UU No. 30 Tahun 2004 tentang Jabatan Notaris, Rafika Adisama, Bandung, p. 24
} 


\subsection{Effects, Barriers and Solutions Object Binding Encumbrance If Not Do in the Face Notary}

\subsubsection{Binding Object Effects In Encumbrance If Not Do in the Face Notary}

In this case the lending or financing conducted by the bank against the debtor, should be making the agreement made with binding guarantees, which meant in this case to protect the interests of banks, and therefore should observe the provisions and legal consequences caused by the binding object assurances that it would receive if the object of encumbrance binding agreement made before the Notary, but if the binding agreement was not done in front Notary Public, the legal consequences arising are: ${ }^{14}$

- An agreement made under the deed in hand or loss of authenticity as stated in Article 16 paragraph (8) UUJN, resulting in the deed can not be registered.

- As the recipient if the imposition of collateral Mortgage Mortgage done under the hands of the lender does not get a position that takes precedence (droit de preference)

- In the event of default, the guarantee can not be directly executed.

- Proof of the deed made does not apply to third parties.

- In case of dispute / dispute between two parties, the completion of which can be reached only through a settlement amicably, can not be passed into law.

- Financing affect member motivation to comply with good performance, it is usually greatly affects the smooth installment members in fulfilling their obligations.

\subsubsection{Barriers and Solutions Object Binding Encumbrance If Not Do in the Face Notary}

In this case the binding object encumbrance or collateral material, should the need for binding Notary for the creation of a legal bond, in order to have a clear legal certainty creditor or debtor with the aim simplify the execution process. As for loading encumbrance if executed before Notary is as follows: ${ }^{15}$

- Phase granting of dependents, with the establishment of the Mortgage Deed Granting Land Deed Official, hereinafter referred to as PPAT, which was preceded by an agreement or secured debts.

- Phase registration by the Land Office, which is currently charged birth mortgages. In its capacity as mentioned above, the deeds made by authentic act PPAT form

So if it is otherwise performed before a Notary in the binding object security rights if it is not done before the Notary will bring obstacles in the execution of mortgage and can be detrimental to both sides of the creditor or debtor of the emergence of such barriers researchers also provide a solution if it happens in researchers will present it in the form of the following table: ${ }^{16}$

\begin{tabular}{cll}
\hline No. & \multicolumn{1}{c}{ Resistance } & \multicolumn{1}{c}{ Solutions } \\
\hline 1 & $\begin{array}{l}\text { Unable to perform a completeness } \\
\text { check on BPN administration making } \\
\text { it difficult to see the collateral in } \\
\text { trouble or not }\end{array}$ & $\begin{array}{l}\text { Providing information to the Bank } \\
\text { about the procedure in the } \\
\text { agreement that was made before } \\
\text { Notary }\end{array}$ \\
\hline 2 & $\begin{array}{l}\text { If you want the execution creditor or } \\
\text { bank can not negotiate even if the }\end{array}$ & $\begin{array}{l}\text { Notary tell parties and explain the } \\
\text { function of an agreement even if }\end{array}$ \\
\hline
\end{tabular}

\footnotetext{
${ }^{14}$ Frans Edho, 2010, Perjanjian Kredit Perbankan, Citra Aditya Bakti, Bandung, p. 135

15 Badriah Aaron, 2010, Penyelesaian Sengketa Kredit Bermasalah: Solusi Hukum (Legal Action) dan Alternatif Penyelesaian Segala Jenis Kredit Bermasalah, Pustaka Yustisia, Yogyakarta, p. 73.

${ }^{16}$ Based on the interview with Novi Gunawan Notary Bank Semarang on December 12, 2019
} 
Volume 6 Issue 4, December 2019

Nationally Accredited Journal,

Decree No. B/4130/E5/E5.2.1/2019

debtor has been informed about the made by deed under the hand sharing system

3 If there is a refinance loan is The bank provides the explanation sometimes the debtor did not inform of the initial agreement that the the bank about the problem so that right collateral if it did take over no syncing on PK. should notify the bank or loan as financing providers that do syncing to PK.

4 Debtors sometimes evasive when've The Bank pointed out to the never signed PK. Borrower archive or file copy to be shown to the debtor stating that the debtor has made a loan agreement.

\section{Closing}

\subsection{Conclusion}

Based on the research results can be concluded as follows:

- Importance leading role of the Notary in Article 15 (1) UUHT determine that importance a strand Attorney Imposing Mortgage (SKMHT) shall be made by notarial deed or deed of PPAT.

- The legal consequences for binding Binding Objects Encumbrance if not done in the presence of a Notary (1) agreements that do lose their authenticity as stated in Article 16 paragraph (8) UUJN, (2) the lender does not get a position that takes precedence (droit de preference), (3) in the event of default, the guarantee can not be directly executed, (4) proof of the deed made does not apply to third parties, so that the settlement be reached only through a settlement amicably, (5) affects the motivation of members financing to meet with a good performance. As for barriers and solutions if the agreement does not do security right before the Notary can be divided into three, namely: (1) prior to binding, the binding associated with the filing requirements as of the identity of the parties,

\subsection{Suggestion}

- It is expected that with the development of the science of law, especially the law guarantees, should the creditors, especially banks continue to promote or serve people who need credit, but retain the principle of prudence in every issue credit and had made an agreement before a Notary.

- Notary should also play a role not only in deed, but also seeks to create a way or chance to be more involved in every legal act. an idea or the way it should be in accordance with the needs of the community and in accordance with the legislation in force.

\section{References}

[1] G.H.S. Lumban Tobing, 1996, Peraturan Jabatan Notaris, Erlangga, Jakarta.

[2] Indrawati Soewarso, 2002, Jaminan-jamian Untuk Pemberian Kredit Menurut Hukum Indonesia, Institut Bankir Indonesia, Jakarta.

[3] Subekti dan Tjitrosudibio, 1995, Terjemahan Kitab Undang-Undang Hukum Perdata (Burgerlijk Wetboek), Cet. XIX, Prad Paramita, Jakarta. 
[4] Soerjono Soekanto \& Sri Mamudji, 2001, Penelitian Hukum Normatif (Suatu Tinjauan Singkat), Rajawali Pers, Jakarta.

[5] Ediwarman, 2010, Monograf, Metodologi Penelitian Hukum, Medan: Program Pascasarjana Univ. Muhammadiyah Sumatera Utara, Medan.

[6] Afifuddin, dkk, 2009, Metodologi Penelitian Kualitatif, Pustaka Setia. Bandung.

[7] Soerjono Soekanto dan Sri Mamudji, 2007, Penelitian Hukum Normatif (Suatu Tinjauan Singkat), Rajagrafindo Persada, Jakarta.

[8] Sjaifurrachman, 2011, Aspek Pertanggungjawaban Notaris Dalam Pembuatan Akta, Mandar Maju, Bandung.

[9] Afkar, Taudikhul, 2017, Analisis Pengaruh Kredit Macet dan Kecukupan Likuiditas Terhadap Efisiensi Biaya Operasional Bank Umum Syariah di Indonesia, Asian Journal of Innovation and Entrepreneurship Vol. 2 No. 2.

[10] Habib Adjie, 2008, Hukum Notaris Indonesia-afsir Tematik Terhadap UU No. 30 Tahun 2004 tentang Jabatan Notaris, Rafika Adisama, Bandung.

[11] Frans Edho, 2010, Perjanjian Kredit Perbankan, Citra Aditya Bakti, Bandung.

[12] Badriah Harun, 2010, Penyelesaian Sengketa Kredit Bermasalah: Solusi Hukum (Legal Action) dan Alternatif Penyelesaian Segala Jenis Kredit Bermasalah, Pustaka Yustisia, Yogyakarta. 